\title{
Consumer Mobile Shopping Acceptance Predictors and Linkages: A Systematic Review and Weight Analysis
}

\author{
Kuttimani Tamilmani ${ }^{1(\bowtie)}$, Nripendra P. Rana ${ }^{1}$, Yogesh K. Dwivedi ${ }^{2}$, \\ and Hatice Kizgin ${ }^{1}$ \\ ${ }^{1}$ International Business, Marketing and Branding Research Centre (IBMB), \\ School of Management, University of Bradford, Richmond Road, \\ Bradford BD7 1DP, UK \\ kuttimani.tamilmani@gmail.com,nrananp@gmail.com, \\ h.kizgin@bradford.ac.uk \\ ${ }^{2}$ Emerging Markets Research Centre (EMaRC), School of Management, \\ Swansea University Bay Campus, Swansea SA1 8EN, UK \\ y.k.dwivedi@swansea.ac.uk,ykdwivedi@gmail.com
}

\begin{abstract}
Mobile phones have become an integral part of human lives with majority of people using them to access product and services for their day-today needs. However, mobile shopping adoption across the globe is not wide or fast as expected. In addition, the research is very scant in understanding various predictors of consumer adoption towards mobile shopping. The objective of this study is to identify most significant and non-significant predictors of consumer mobile shopping acceptance. Systematic review and weight analysis on 34 mobile shopping studies revealed researchers mostly employed TAM and UTAUT model as theoretical lens. This study found an interesting revelation that extrinsic motivation variables such as social influence and perceived usefulness determine consumer mobile shopping behavioral intention during early stages. However, in later stages intrinsic motivation variables such as satisfaction and trust play crucial role to emerge as best and promising predictor of consumer continuous intention respectively.
\end{abstract}

Keywords: Mobile shopping $\cdot$ Weight analysis $\cdot$ Continuous intention

\section{Introduction}

Mobile technologies are the most adopted form of consumer technology across the world in $21^{\text {st }}$ century with 5 billion unique mobile subscribers in 2017, which encompasses two thirds of global population [1]. The characteristics of smartphones with wireless Internet enable consumers to purchase goods and services from anywhere at any time, even in the absence wired broadband connections popularly known as mobile shopping [2]. It empowers consumer with ability to search, browse, compare, and purchase products and services through wireless handheld mobile devices. And, 
they can buy range of products and services such as electronics, apparels, housewares, books, tickets, beauty, and grocery to name a few [3-5]. The unprecedented smartphones adoption rate is in turn fuelling the mobile shopping growth to reshape the online retail environment. Leading market research firm Statista report suggests that mobile e-commerce is poised for growth globally and could possibly rake in upwards of 3.5 trillion USD constituting almost three quarters $(72.9 \%)$ of all e-commerce sales [6]. Mobile phones unique characteristics enable organisations to reach right consumers anytime anywhere through mobile advertising [7, 8]. Organisation's spend on mobile advertising is on upward trajectory with a whopping amount of 105.95 billion USD in 2017 and an estimated amount of 175.64 billion USD in 2020 [9].

The above discussion underscores the central role of mobile phones as a medium for shopping to consumers and advertising to organisations respectively. Despite the potential of mobile technology, mobile readiness report on Fortune 500 companies' mobile websites revealed just one-quarter had mobile-responsiveness and majority of the companies were unprepared [10]. The majority of existing consumer on mobile shopping acceptance studies focused on intention related outcome variables such as behavioural intention [11-13], purchase intention [14, 15], and continuous intention $[16,17]$ rather than use behaviour. Mobile shopping adoption can be achieved at faster rate based on the learning from existing research on this topic across different countries. Existing review articles on mobile shopping mostly provide descriptive information e.g., $[18,19]$ without highlighting on the effective predictors necessary for successful adoption. Therefore, the objective of this study is to employ weight-analysis to synthesise existing findings on mobile shopping and identify the most/least frequently used predictors, and among these the best, worst, and promising predictors [20, 21]. This study will undertake following steps to fulfil the objective:

- Locate consumer focused mobile shopping empirical studies that employed consumer intention/use behaviour-based outcome variables.

- Conduct weight analysis on the empirical studies to understand the significant and non-significant path relationships and their performance.

The remaining sections of this paper is structured as follows: The following section i.e. Sect. 2 describes the research method employed in this study; Sect. 3 presents the findings of weight analysis and systematic literature review followed by discussion in Sect. 4 and conclusion in Sect. 5 .

\section{Research Method}

This study deemed a combination of "systematic review", "Keyword search" and "weight-analysis" techniques as appropriate methodology to synthesize the existing research findings on consumer intention and usage towards mobile shopping [22-31]. It employed keyword based search in the Scopus, Web of Science, and EBSCO 
Business Source complete databases with search terms such as "mobile shopping" OR "m-shopping" OR "mobile purchasing" AND "Adoption" OR "Acceptance" OR "Diffusion" OR "Usage" OR "Intention" to locate articles related to mobile shopping. The initial search from the year 2009 to 2019 resulted in 72 articles. On further screening, it was found that some of the articles were not accessible through researcher's library and numerous studies employed outcome variables other than consumer intention and usage towards mobile shopping. Such instances include but are not limited to outcome variables such as switching intention [32], loyalty [33], and patronage [34]. Therefore, studies that did not report relevant data for weight analysis were also excluded resulting in 34 final manuscripts that focussed only on consumer intention and usage as outcome variable to qualify for weight analysis.

\section{Findings}

This section presents and explains the findings from the systematic review and weight analysis.

\subsection{Dominant Theories/Models}

Researchers employed as much as thirteen unique theories/models as theoretical lens across the 34 studies to examine consumer intention and usage towards mobile shopping. Table 1 provides summary of dominant theories that are employed on two or more instances. Technology acceptance model (TAM) emerged as the most dominant theory with as much as 12 studies adapting TAM as theoretical lens by often extending the model with external constructs. For instance, Groß [35] extended TAM with perceived enjoyment and trust and found these attributes as significant predictor of consumers mobile shopping in Germany. Venkatesh, Morris, Davis and Davis [36]'s, UTAUT theory emerged as the distant second most popular theory with five research investigations. Three studies adapted Expectancy Confirmation Model making it the third most popular theoretical lens in the consumer mobile shopping acceptance arena. Multifaceted trust-risk model and theory of planned behaviour jointly occupied fourth position by serving as theoretical lens on two instances each. Furthermore, there were eight theories/models such as (1) 4P's marketing theory [16], (2) Behavioural reasoning theory [37], (3) Elaboration likelihood model [38], (4) Flow theory [39], (5) IS success model [14], (6) Stimulus-Organism-Response (SOR) framework [40], (7) Technology readiness [41], and (8) Trust transfer theory [15] that researchers employed on one instance each. Finally, there were two studies $[42,43]$ that did not employ any dominant theories to examine consumer mobile shopping acceptance. 
Table 1. Dominant mobile shopping acceptance theories/models

\begin{tabular}{l|l|l}
\hline Theory/model & Frequency & References \\
\hline $\begin{array}{l}\text { Technology acceptance } \\
\text { model (TAM) }\end{array}$ & 12 & $\begin{array}{l}\text { Agrebi and Jallais [3]; Chen, Hsu and Lu } \\
\text { [44]; Groß [35]; Groß [45]; Ko, Kim and Lee } \\
\text { [5]; Lu and Su [46]; Natarajan, } \\
\text { Balasubramanian and Kasilingam [47]; San- } \\
\text { Martín, López-Catalán and Ramón-Jerónimo } \\
\text { [11]; Saprikis, Markos, Zarmpou and } \\
\text { Vlachopoulou [48]; Shang and Wu [49]; } \\
\text { Wong, Lee, Lim, Chua and Tan [12]; Wong, } \\
\text { Tan, Ooi and Lin [13] }\end{array}$ \\
$\begin{array}{ll}\text { Chau, Seshadri, Broekemier and } \\
\text { Pamornpathomkul [50]; Lu, Yu, Liu and Wei } \\
\text { [51]; Tan and Ooi [52]; Yang and Forney } \\
\text { [53]; Yang [54] }\end{array}$ \\
$\begin{array}{ll}\text { Unified theory of acceptance } \\
\text { and use of technology } \\
\text { (UTAUT) }\end{array}$ & 5 & $\begin{array}{l}\text { Chung, Chun and Choi [17]; Hung, Yang and } \\
\text { Hsieh [55]; Kang, Hung, Yang, Hsieh and } \\
\text { Tang [56] }\end{array}$ \\
\hline $\begin{array}{l}\text { Expectancy confirmation } \\
\text { model }\end{array}$ & 3 & $\begin{array}{l}\text { Groß [57]; Marriott and Williams [58] } \\
\text { Prodanova, San-Martín and Jimenez [59]; } \\
\text { Yang [60] }\end{array}$ \\
\hline $\begin{array}{l}\text { Multifaceted trust-risk model } \\
\text { Theory of planned behaviour }\end{array}$ & 2 &
\end{tabular}

\subsection{Weight Analysis}

Weight analysis technique determines indicative predictive power of an independent variable over dependant variable. This is performed by calculating weight, which is as a ratio of total number of significant relationships between an independent and dependant variable (a) to the total number of all relationships between these two variables (b) and thus weight is calculated using formula (a)/(b) [21].

\section{Coding Independent and Dependent Variables}

This study employed generalized coding scheme adapted from Jeyaraj, Rottman and Lacity [21], to uniformly code findings between various independent and dependant variables among the 34 consumer mobile shopping studies. The coding template comprised of 'rows' and 'columns'. Each row in the template represented one of the 34 studies, while each column represented the path relationship between an independent and a dependant variable. The intersection points between studies in a "row" and path relationship in the "column" captured the significance of the particular path relationship corresponding to that study. The coding scheme has four different values: (1) ' +1 ' in the case where the path relationship examined was significant and hypothesized in positive direction; (2) ' -1 ' in the case where the path relationship examined was significant and hypothesized in negative direction; (3) ' 0 ' in the case where the path relationship examined was non-significant; and (4) "Blank" when the relationship was not studied [21]. This study thoroughly examined all the hypotheses in the 34 articles to identify various dependent and independent variables that researchers employed to examine consumer mobile shopping acceptance. The examination resulted in 
Table 2. Most frequently studied variables in mobile shopping

\begin{tabular}{|c|c|c|c|}
\hline $\begin{array}{l}\text { Sl. } \\
\text { no }\end{array}$ & $\begin{array}{l}\text { Independent } \\
\text { variable }\end{array}$ & Definition & Example citation(s) \\
\hline 1 & Anxiety & $\begin{array}{l}\text { Refers to negative emotions in cognitive } \\
\text { states that are evoked during actual or } \\
\text { imaginary interactions with underlying } \\
\text { behaviour (e.g. Using mobile for } \\
\text { shopping) [61] }\end{array}$ & $\begin{array}{l}\mathrm{Lu} \text { and } \mathrm{Su}[46] ; \text { Saprikis, Markos, } \\
\text { Zarmpou and Vlachopoulou [48] }\end{array}$ \\
\hline 2 & Attitude & $\begin{array}{l}\text { The extent to which individuals have } \\
\text { positive or negative evaluation about the } \\
\text { behaviour under question [62] }\end{array}$ & $\begin{array}{l}\text { Groß [45]; Gupta and Arora [37]; Yang } \\
\text { [54]; Yang [60] }\end{array}$ \\
\hline 3 & Compatibility & $\begin{array}{l}\text { The degree to which an innovation is } \\
\text { perceived to be consistent with the } \\
\text { values, past experiences, and needs of } \\
\text { potential adopters [63] }\end{array}$ & $\begin{array}{l}\text { Lu and Su [46], Wong, Tan, Ooi and Lin } \\
\text { [13] }\end{array}$ \\
\hline 4 & $\begin{array}{l}\text { Facilitating } \\
\text { conditions }\end{array}$ & $\begin{array}{l}\text { The degree to which an individual } \\
\text { believes that an organisational and } \\
\text { technical infrastructure exists to support } \\
\text { use of the system [36] }\end{array}$ & Tan and Ooi [52]; Yang [54] \\
\hline 5 & $\begin{array}{l}\text { Perceived } \\
\text { behavioural } \\
\text { control }\end{array}$ & $\begin{array}{l}\text { Individuals perception of his/her } \\
\text { capability to performing a behaviour of } \\
\text { interest [62] }\end{array}$ & $\begin{array}{l}\text { San-Martín, López-Catalán and Ramón- } \\
\text { Jerónimo [11], Yang [60] }\end{array}$ \\
\hline 6 & $\begin{array}{l}\text { Perceived ease } \\
\text { of use }\end{array}$ & $\begin{array}{l}\text { The degree to which a person believes } \\
\text { that using a particular system would be } \\
\text { free of effort [64] }\end{array}$ & $\begin{array}{l}\text { Hew, Leong, Tan, Lee and Ooi [40], } \\
\text { Natarajan, Balasubramanian and } \\
\text { Kasilingam [47], Saprikis, Markos, } \\
\text { Zarmpou and Vlachopoulou [48], Tan } \\
\text { and Ooi [52] }\end{array}$ \\
\hline 7 & $\begin{array}{l}\text { Perceived } \\
\text { enjoyment }\end{array}$ & $\begin{array}{l}\text { The extent to which the activity of using } \\
\text { a computer/particular system is perceived } \\
\text { to be enjoyable in its own right, apart } \\
\text { from any performance consequences that } \\
\text { may be anticipated [65] }\end{array}$ & $\begin{array}{l}\text { Natarajan, Balasubramanian and } \\
\text { Kasilingam [47], Saprikis, Markos, } \\
\text { Zarmpou and Vlachopoulou [48], Tan } \\
\text { and Ooi [52], Wong, Tan, Ooi and Lin } \\
\text { [13] }\end{array}$ \\
\hline 8 & Perceived risk & $\begin{array}{l}\text { Consumers' expectation of losses } \\
\text { associated with purchasing and acts as an } \\
\text { inhibitor of purchase behaviour [66] }\end{array}$ & $\begin{array}{l}\text { Marriott and Williams [58], Natarajan, } \\
\text { Balasubramanian and Kasilingam [47], } \\
\text { Tan and Ooi [52,12] }\end{array}$ \\
\hline 9 & $\begin{array}{l}\text { Perceived } \\
\text { usefulness }\end{array}$ & $\begin{array}{l}\text { The degree to which a person believes } \\
\text { that using a particular system would } \\
\text { enhance his or her job performance [64] }\end{array}$ & $\begin{array}{l}\text { Natarajan, Balasubramanian and } \\
\text { Kasilingam [47], Tan and Ooi [52], } \\
\text { Wong, Tan, Ooi and Lin [13] }\end{array}$ \\
\hline 10 & $\begin{array}{l}\text { Personal } \\
\text { innovativeness }\end{array}$ & $\begin{array}{l}\text { The willingness of an individual to try } \\
\text { out any new information technology [67] }\end{array}$ & $\begin{array}{l}\text { Natarajan, Balasubramanian and } \\
\text { Kasilingam [47], Saprikis, Markos, } \\
\text { Zarmpou and Vlachopoulou [48], Wong, } \\
\text { Tan, Ooi and Lin [13] }\end{array}$ \\
\hline 11 & Satisfaction & $\begin{array}{l}\text { The psychological or emotional state } \\
\text { resulting from a cognitive assessment of } \\
\text { the gap between the expectations and the } \\
\text { actual performance of an information } \\
\text { system [68] }\end{array}$ & $\begin{array}{l}\text { Agrebi and Jallais [3], Amoroso [42], } \\
\text { Natarajan, Balasubramanian and } \\
\text { Kasilingam [47] }\end{array}$ \\
\hline 12 & $\begin{array}{l}\text { Social } \\
\text { influence }\end{array}$ & $\begin{array}{l}\text { The degree to which an individual } \\
\text { perceives that important others believe } \\
\text { he or she should use the new system [36] }\end{array}$ & $\begin{array}{l}\text { Groß [45], San-Martín, López-Catalán } \\
\text { and Ramón-Jerónimo [11], Tan and Ooi } \\
\text { [52], Yang and Forney [53] }\end{array}$ \\
\hline
\end{tabular}


Table 2. (continued)

\begin{tabular}{|c|c|c|c|}
\hline $\begin{array}{l}\text { Sl. } \\
\text { no }\end{array}$ & $\begin{array}{l}\text { Independent } \\
\text { variable }\end{array}$ & Definition & Example citation(s) \\
\hline 13 & Trust & $\begin{array}{l}\text { The most important factor for } \\
\text { establishing relationships, both of } \\
\text { interpersonal and commercial nature } \\
\text { between two or more parties that } \\
\text { determine their future action [69] }\end{array}$ & $\begin{array}{l}\text { Groß [35], Marriott and Williams [58], } \\
\text { Tan and Ooi [52] }\end{array}$ \\
\hline 14 & $\begin{array}{l}\text { Trust in } \\
\text { mobile vendor }\end{array}$ & $\begin{array}{l}\text { Comprises of consumer's trusting beliefs } \\
\text { (e.g. ability, integrity, and benevolence) } \\
\text { and their intention to engage in a } \\
\text { business relationship with m-vendors by } \\
\text { providing personal information, } \\
\text { following the m-vendor's advice, or } \\
\text { making purchases and transferring } \\
\text { money directly via smartphone Groß [57] }\end{array}$ & Groß [57] \\
\hline $\begin{array}{l}\text { Sl. } \\
\text { no }\end{array}$ & $\begin{array}{l}\text { Dependent } \\
\text { variables }\end{array}$ & Definition & Example citation(s) \\
\hline 1 & $\begin{array}{l}\text { Behavioural } \\
\text { intention }\end{array}$ & $\begin{array}{l}\text { Represents individual intention to } \\
\text { perform an underlying behaviour with } \\
\text { stronger intentions leading to higher } \\
\text { chances of performing the underlying } \\
\text { behaviour [62] }\end{array}$ & Groß [35], Groß [45], Yang [54] \\
\hline 2 & $\begin{array}{l}\text { Continuous } \\
\text { intention }\end{array}$ & $\begin{array}{l}\text { This refers to consumers in post- } \\
\text { purchase stage, where their consumption } \\
\text { experience determines the future } \\
\text { behaviour [70] }\end{array}$ & $\begin{array}{l}\text { Gao, Waechter and Bai [39], Hung, } \\
\text { Yang and Hsieh [55], Kang, Hung, } \\
\text { Yang, Hsieh and Tang [56], Groß [57] }\end{array}$ \\
\hline 3 & Use behaviour & $\begin{array}{l}\text { The degree and manner in which } \\
\text { customers utilise the capabilities of an } \\
\text { underlying technology/system [71] }\end{array}$ & Groß [35], Groß [45] \\
\hline
\end{tabular}

identifying 41 independent variables, five dependent variables, and 59 different path relationships among these independent and dependent variables. However, the findings of this study are limited to path relationships that are examined on two or more instances. This resulted in final 14 independent variables, three dependant variables i.e. behavioural intentional, continuous intention, and use behaviour and their 20 path relationships. Table 2 provides summary and definition of the final 14 independent variables ranging from anxiety to trust in mobile vendor and three dependent variables.

\section{Dominant Predictors of Mobile Shopping Acceptance}

Weight analysis classifies independent variables into two types based on the numbers of times the variable is used a predictor on a dependent variable. An independent variable is termed as 'well-utilized' predictor when examined by researchers in five or more studies. Otherwise, the independent variable is considered as an 'experimental' predictor in case of less than five examinations. Furthermore, the independent variable qualifies as the best predictor of dependant variable when they are used in five or more studies (well-utilized) and have a weight of 0.80 or more. On the other hand, independent variable can be considered as a promising predictor when it is used in less than 
five studies (experimental) and have perfect weight of one [21]. The summary of weight analysis findings for all the three dependant variables behavioural intentional, continuous intention, and use behaviour is depicted in Table 3.

\section{Well Utilized Predictors of Behavioural Intention}

Six variables fulfilled the criteria (five or more examinations) to qualify as the well utilized predictor of consumer behavioural intention towards mobile shopping. The following three predictors: perceived usefulness/performance expectancy (examined 11 times, significant 11 times), attitude (examined 8 times, significant 8 times), and social influence (examined 6 times, significant 6 times) fell under the 'best predictor' category. Since, these variables were explored five or more times and have a weight equal to or greater than 0.80 . The remaining three 'well utilized' predictors 'perceived enjoyment' (examined 9 times, significant 6 times), satisfaction (examined 5 times, significant 3 times), and perceived ease of use/effort expectancy (examined 9 times, significant 4 times) having weight of $0.67,0.60$, and 0.44 respectively are termed as least effective predictor and needs further examination.

\section{Experimental Predictors of Behavioural Intention}

Notwithstanding the six 'well utilized' predictors behavioural intention also had seven experimental predictors such as: (1) perceived risk, (2) personal innovativeness, (3) trust, (4) compatibility, (5) anxiety, (6) facilitating conditions, and (7) perceived behavioural control. From the seven aforementioned 'experimental predictors' only two predictors such as: compatibility (examined 2 times, significant 2 times) and perceived behavioural control (examined 2 times, significant 2 times) with perfect weight of one, qualified as the promising predictors of consumer behavioural intention towards mobile shopping.

\section{Predictors of Continuous Intention}

There were five dominant predictors in determining consumer continuous intention towards mobile shopping. The first one is satisfaction that qualified both as a well utilized and best predictor of consumer continuous intention with significant results on all five instances of examination. The remaining four predictors such as: (1) trust (examined 3 times, significant 3 times); (2) trust in mobile vendor (3) perceived risk (examined 2 times, significant 2 times); and (4) perceived usefulness/performance expectancy (examined 2 times, significant ' 0 ' times) each with less than five examinations emerged as 'experimental predictors'. The first three 'experimental predictors' of continuous intention (trust, trust in mobile vendor, and perceived risk) also qualified as promising predictor perfect weight of one. Meanwhile, perceived usefulness/ performance expectancy emerged as the as least effective predictor of continuous intention.

\section{Predictors of Use Behaviour}

Use behaviour comprised of only two experimental predictors with less than five examination such as 'satisfaction' (examined 2 times, significant 2 times) and 'behavioural intention' (examined 2 times, significant 2 times). This indicates researchers scarcely employed use behaviour as outcome variable in consumer mobile shopping acceptance research. Both the experimental predictors qualified as the promising predictors of use behaviour with perfect weight of one. 
Table 3. Weight analysis summary approach adapted from Jeyaraj, Rottman and Lacity [21]

\begin{tabular}{|c|c|c|c|c|c|c|}
\hline $\mathrm{SN}$ & Independent variable & DV & $\begin{array}{l}\text { Sig } \\
\text { (a) }\end{array}$ & $\begin{array}{l}\text { Non- } \\
\text { Sig }\end{array}$ & $\begin{array}{l}\text { Total } \\
\text { (b) }\end{array}$ & $\begin{array}{l}\text { Weight } \\
(\mathrm{a} / \mathrm{b})\end{array}$ \\
\hline 1 & $\begin{array}{l}\text { Perceived usefulness/performance } \\
\text { expectancy }\end{array}$ & \multirow[t]{13}{*}{ BI } & 11 & 0 & 11 & 1.00 \\
\hline 2 & $\begin{array}{l}\text { Perceived ease of use/effort } \\
\text { expectancy }\end{array}$ & & 4 & 5 & 9 & 0.44 \\
\hline 3 & Perceived enjoyment & & 6 & 3 & 9 & 0.67 \\
\hline 4 & Attitude & & 8 & 0 & 8 & 1.00 \\
\hline 5 & Social influence & & 6 & 0 & 6 & 1.00 \\
\hline 6 & Satisfaction & & 3 & 2 & 5 & 0.60 \\
\hline 7 & Perceived risk & & 3 & 1 & 4 & 0.75 \\
\hline 8 & Personal innovativeness & & 2 & 1 & 3 & 0.67 \\
\hline 9 & Trust & & 2 & 1 & 3 & 0.67 \\
\hline 10 & Compatibility & & 2 & 0 & 2 & 1.00 \\
\hline 11 & Anxiety & & 1 & 1 & 2 & 0.50 \\
\hline 12 & Facilitating conditions & & 1 & 1 & 2 & 0.50 \\
\hline 13 & Perceived behavioural control & & 2 & 0 & 2 & 1.00 \\
\hline 14 & Satisfaction & \multirow[t]{5}{*}{$\mathrm{CI}$} & 5 & 0 & 5 & 1.00 \\
\hline 15 & Trust & & 3 & 0 & 3 & 1.00 \\
\hline 16 & Trust in mobile vendor & & 2 & 0 & 2 & 1.00 \\
\hline 17 & Perceived risk & & 2 & 0 & 2 & 1.00 \\
\hline 18 & $\begin{array}{l}\text { Perceived usefulness/performance } \\
\text { expectancy }\end{array}$ & & 0 & 2 & 2 & 0.00 \\
\hline 19 & Satisfaction & \multirow[t]{2}{*}{ UB } & 2 & 0 & 2 & 1.00 \\
\hline 20 & Behavioural intention & & 2 & 0 & 2 & 1.00 \\
\hline
\end{tabular}

[Legend: BI: Behavioural Intention; CI: Continuous Intention; DV: Independent Variable; NonSig: Number of non-significant path values; Sig (a): Number of significant path values; UB: Use Behaviour]

\section{Discussion}

Literature synthesis on consumer mobile shopping acceptance studies reveal that researchers to date have mostly employed theories such as TAM and UTAUT. These theories were originally developed in the organisational context with major focus on individual employee characteristics and their motivation in using underlying technologies to improve job related outcomes. In addition, perceived usefulness similar to performance expectancy (11 studies) and perceived ease of use (9 studies) similar to effort expectancy the two independent variables of technology acceptance model (TAM) emerged as the most utilized variables emphasising TAM's dominance in individual adoption research. Besides individual characteristics from dominant technology acceptance theories, researchers have scarcely employed theories such as IS success model e.g., $[16,72]$ and flow theory e.g., $[39,52]$ to evaluate impact of system characteristics such as system quality, information quality, and system flow experience 
on consumer mobile shopping acceptance. The preceding discussion reveals researches mostly deployed theories developed in the organisation context as theoretical lens and seldom employed consumer-focused theories such as extended unified theory of acceptance and use of technology (UTAUT2) to examine mobile shopping acceptance.

The weight analysis findings reveal an interesting pattern that the role and relevance of various attributes depend upon the time period when the consumer starts using the underlying technology. The best predictors of consumer behavioural intention, which refers to early and potential users of technology are perceived usefulness, attitude, and social influence. This is followed by compatibility and perceived behavioural control that emerged as most promising predictors with all significant results for early mobile shopping users. However, attributes such as satisfaction, trust, and perceived risk emerged as least effective predictors of consumer behavioural intention. The plausible explanation could be early users haven't utilized the technology enough and/or bought product/service to evaluate their satisfaction, trust, and risk level of both the platform and vendors.

Interestingly, for consumers in the post-purchase stage, 'satisfaction' emerged as the single most well utilized and best predictor of their continuous intention. In addition, attributes such as trust, perceived risk, and trust in mobile vendor emerged as the promising predictor with all significant results. This underscores the significant role of both the platform and vendors in sustaining the existing consumers and influencing their continuous intention for future transactions. The emergence of variables such as Trust in mobile vendor as promising predictor only for continuous intention and not for behavioural intention further validates the role of product/service providers in improving the longevity of consumers towards mobile shopping. Surprisingly, perceived usefulness/performance expectancy that was best predictor of behavioural intention became least effective predictor of consumer continuous intention towards mobile shopping. The plausible explanation for this pattern comes from Hung, Yang and Hsieh [55] study that extended Expectation-Confirmation model with Trust to examine consumer continuous intention towards mobile shopping. The study results among 244 consumers found that extrinsic motivation variable perceived usefulness became non-significant determinant of continuous intention over time. However, during repurchasing activities, intrinsic motivation variable 'trust' explained the most variance on consumer continuous intention towards mobile shopping followed by Satisfaction. Finally, both Satisfaction and Behavioural intention the two predictors of Use behaviour emerged as promising predictor with all significant results. The preceding discussion indicates Use behaviour is sparingly examined as outcome variable in consumer mobile shopping acceptance. This pattern is understandable as consumer mobile shopping is still at nascent stages of acceptance in many parts of the world and researchers are trying to measure the intention rather than actual behaviour [20]. However, $\mathrm{Wu}$ and $\mathrm{Du}$ [73] meta-analysis on BI and UB caution the notion of IS researchers considering BI as surrogate of UB. Because, individual's use behaviour towards technology cannot be measured without assessing their actual system usage. Furthermore, $\mathrm{Wu}$ and $\mathrm{Du}$ [73] cautioned research community that they should be circumspect of studies that measure only behavioural intention without investigating use behaviour. Figure 1 depicts the resultant model emerging from weight analysis on mobile shopping empirical studies. 


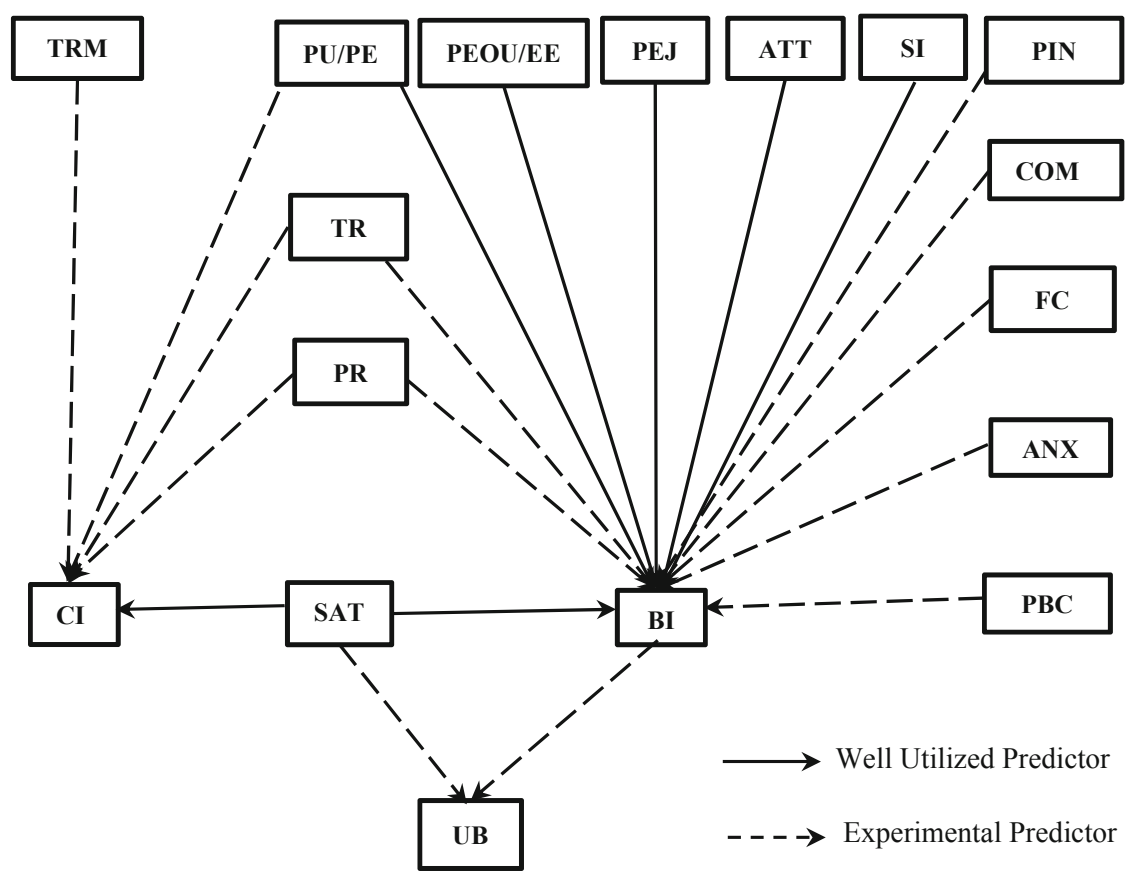

[LEGEND: ANX: Anxiety; AT: Attitude; BI: Behavioural Intention; COM: Compatibility; CI: Continuous Intention; FC: Facilitating Conditions; PBC: Perceived Behavioural Control; PEOU/EE: Perceived Ease of Use/ Effort Expectancy; PEJ: Perceived Enjoyment; PR: Perceived Risk; PU/PE: Perceived Usefulness/ Performance Expectancy; PIN: Personal Innovativeness; SAT: Satisfaction; SI: Social Influence; TR: Trust; TRMV: Trust in Mobile Vendor; UB: Use Behaviour]

Fig. 1. Emergent model of mobile shopping weight-analysis

\section{Conclusion}

This study identified various predictors of consumer mobile shopping acceptance and their linkage by synthesising findings from extant literature through weight analysis. The findings emerging from this study is important for future researchers in this domain and practitioners alike. Weight analysis results found among fourteen unique independent variables (Table 3) only four emerged as the best predictor three on behavioural intention (perceived usefulness, attitude, and social influence) and one on continuous intention (Satisfaction). This is followed by five promising predictor two on behavioural intention (compatibility, perceived behavioural control) and three on continuous intention (trust, trust in mobile vendor, and perceived risk), which are more likely candidates to emerge as best predictor in future. Therefore, researchers should continue using promising predictors while investigating consumer mobile shopping acceptance alongside the best predictors. The remaining five final independent variables perceived ease of use, perceived enjoyment, personal innovativeness, anxiety, 
and facilitating conditions emerged only as least effective predictors on consumer mobile shopping acceptance endogenous variables. Perceived ease of use one of the core construct of TAM, despite being the second most frequently used predictor produced the most non-significant results. Therefore, researchers should be more cautious while operationalizing this type of construct in their research model. They should make necessary adaptations and/or omit irrelevant constructs such as least effective predictors from the model depending upon context rather than having obligation to replicate all the constructs in underpinning model/theory. Moreover, the review found almost half $47 \%$ studies in consumer mobile shopping arena employed theories developed under organisational context such as TAM and UTAUT. Therefore, future researchers should employ more consumer focussed theories such as UTAUT2.

Notwithstanding the precautionary measures taken for coding and analysis, the findings of this study is not without its limitations. First the studies involved for weight analysis were limited only to three databases such as Scopus, Web of Science, and EBSCO Business Source complete restricting the total number of empirical studies available for weight analysis. In future, researchers should widen their search horizon to more databases that will increase the number of studies available for analysis and minimize publication bias. Second, weight analysis does not take sample size into consideration like meta-analysis and cannot provide true effect size in a path relationship. In future, researchers should try to combine meta-analysis with weight analysis to calculate the true-effect size of path relationships. Third, this research included studies that employed intention and use related outcome variables pertaining to consumer mobile shopping acceptance. In future, researchers should include all outcome variables to provide comprehensive overview on various outcomes measured in consumer mobile shopping acceptance arena and their predictors. Finally, this study included only quantitative studies that reduced final number of studies available for analysis. Future studies should include both qualitative and quantitative studies in weight analysis.

\section{References}

1. GSMA Intelligence: Global Mobile Trends 2017. https://www.gsmaintelligence.com/ research/?file=3df1b7d57b1e63a0cbc3d585feb82dc2\&download. Accessed 01 June 2019

2. Tan, G.W.-H., Lee, V.-H., Wong, C.-H., Ooi, K.-B.: Mobile shopping: the new retailing industry in the 21st century. Encyclopedia of E-Commerce Development, Implementation, and Management, pp. 1448-1460. IGI Global (2016)

3. Agrebi, S., Jallais, J.: Explain the intention to use smartphones for mobile shopping. J. Retail. Consum. Serv. 22, 16-23 (2015)

4. Cheng, Y.-H., Huang, T.-Y.: High speed rail passengers' mobile ticketing adoption. Transp. Res. Part C Emerg. Technol. 30, 143-160 (2013)

5. Ko, E., Kim, E.Y., Lee, E.K.: Modeling consumer adoption of mobile shopping for fashion products in Korea. Psychol. Mark. 26, 669-687 (2009)

6. Statista: Mobile E-commerce is up and poised for further growth. https://www.statista.com/ chart/13139/estimated-worldwide-mobile-e-commerce-sales/. Accessed 01 July 2019 
7. Maneesoonthorn, C., Fortin, D.: Texting behaviour and attitudes toward permission mobile advertising: an empirical study of mobile users' acceptance of SMS for marketing purposes. Int. J. Mob. Mark. 1, 66-72 (2006)

8. Yang, K.C.: Exploring factors affecting consumer intention to use mobile advertising in Taiwan. J. Int. Consum. Mark. 20, 33-49 (2007)

9. Statista: Mobile advertising spending worldwide from 2007 to 2022. https://www.statista. com/statistics/303817/mobile-internet-advertising-revenue-worldwide/. Accessed 01 Aug 2019

10. McCorkindale, T., Morgoch, M.: An analysis of the mobile readiness and dialogic principles on Fortune 500 mobile websites. Public Relat. Rev. 39, 193-197 (2013)

11. San-Martín, S., López-Catalán, B., Ramón-Jerónimo, M.A.: Mobile shoppers: types, drivers, and impediments. J. Organ. Comput. Electr. Commer. 23, 350-371 (2013)

12. Wong, C.H., Lee, H., Lim, Y.H., Chua, B.H., Tan, G.: Predicting the consumers' intention to adopt mobile shopping: an emerging market perspective. Int. J. Netw. Mob. Technol. 3, 24 39 (2012)

13. Wong, C.H., Tan, G.W.H., Ooi, K.B., Lin, B.: Mobile shopping: the next frontier of the shopping industry? An emerging market perspective. Int. J. Mob. Commun. 13, 92-112 (2014)

14. Chen, L.Y.: Antecedents of customer satisfaction and purchase intention with mobile shopping system use. Int. J. Serv. Oper. Manag. 15, 259-274 (2013)

15. Zhou, T.: An empirical examination of the determinants of mobile purchase. Pers. Ubiquit. Comput. 17, 187-195 (2013)

16. Chen, H.-J.: What drives consumers' mobile shopping? 4Ps or shopping preferences? Asia Pac. J. Mark. Logist. 30, 797-815 (2018)

17. Chung, D., Chun, S.G., Choi, H.Y.: Empirical study on determinants for the continued use of mobile shopping apps. Issues Inf. Syst. 17, 34-43 (2016)

18. Shankar, V., Kleijnen, M., Ramanathan, S., Rizley, R., Holland, S., Morrissey, S.: Mobile shopper marketing: key issues, current insights, and future research avenues. J. Interact. Mark. 34, 37-48 (2016)

19. Marriott, H.R., Williams, M.D., Dwivedi, Y.K.: What do we know about consumer mshopping behaviour? Int. J. Retail Distrib. Manag. 45, 568-586 (2017)

20. Tamilmani, K., Rana, N.P., Dwivedi, Y.K.: Mobile application adoption predictors: systematic review of UTAUT2 studies using weight analysis. In: Al-Sharhan, S.A., et al. (eds.) I3E 2018. LNCS, vol. 11195, pp. 1-12. Springer, Cham (2018). https://doi.org/10. 1007/978-3-030-02131-3_1

21. Jeyaraj, A., Rottman, J.W., Lacity, M.C.: A review of the predictors, linkages, and biases in IT innovation adoption research. J. Inf. Technol. 21, 1-23 (2006)

22. Tamilmani, K., Rana, N.P., Dwivedi, Y.K.: Use of 'habit' is not a habit in understanding individual technology adoption: a review of UTAUT2 based empirical studies. In: Elbanna, A., Dwivedi, Y.K., Bunker, D., Wastell, D. (eds.) TDIT 2018. IAICT, vol. 533, pp. 277294. Springer, Cham (2019). https://doi.org/10.1007/978-3-030-04315-5_19

23. Tamilmani, K., Rana, N.P., Dwivedi, Y.K., Sahu, G.P., Roderick, S.: Exploring the role of 'price value' for understanding consumer adoption of technology: a review and metaanalysis of UTAUT2 based empirical studies. In:Twenty-Second Pacific Asia Conference on Information Systems Japan (2018)

24. Tamilmani, K., Rana, N.P., Dwivedi, Y.K.: A systematic review of citations of UTAUT2 article and its usage trends. In: Kar, A.K., et al. (eds.) I3E 2017. LNCS, vol. 10595, pp. 38 49. Springer, Cham (2017). https://doi.org/10.1007/978-3-319-68557-1_5 
25. Tamilmani, K., Rana, N.P., Alryalat, M.A.A., Al-Khowaiter, W.A., Dwivedi, Y.K.: Social media research in the context of emerging markets: an analysis of extant literature from information systems perspective. J. Adv. Manag. Res. 15, 115-129 (2018)

26. Dwivedi, Y.K., Rana, N.P., Jeyaraj, A., Clement, M., Williams, M.D.: Re-examining the unified theory of acceptance and use of technology (UTAUT): towards a revised theoretical model. Inf. Syst. Front. 21, 719-734 (2019)

27. Ismagilova, E., Slade, E.L., Rana, N.P., Dwivedi, Y.K.: The effect of electronic word of mouth communications on intention to buy: a meta-analysis. Inf. Syst. Front. 1-24 (2019). https://doi.org/10.1007/s10796-019-09924-y

28. Dwivedi, Y.K., Ismagilova, E., Rana, N.P., Weerakkody, V.: Use of social media by b2b companies: systematic literature review and suggestions for future research. In: Pappas, I.O., Mikalef, P., Dwivedi, Y.K., Jaccheri, L., Krogstie, J., Mäntymäki, M. (eds.) I3E 2019. LNCS, vol. 11701, pp. 345-355. Springer, Cham (2019). https://doi.org/10.1007/978-3-03029374-1_28

29. Ismagilova, E., Slade, E., Williams, M.: Persuasiveness of eWOM communications: literature review and suggestions for future research. In: Dwivedi, Y.K., et al. (eds.) I3E 2016. LNCS, vol. 9844, pp. 354-359. Springer, Cham (2016). https://doi.org/10.1007/9783-319-45234-0_32

30. Waseem, D., Biggemann, S., Garry, T.: Value co-creation: the role of actor competence. Ind. Mark. Manag. 70, 5-12 (2018)

31. Juntunen, M., Ismagilova, E., Oikarinen, E.-L.: B2B brands on Twitter: engaging users with a varying combination of social media content objectives, strategies, and tactics. Ind. Mark. Manag. (2019). https://doi.org/10.1016/j.indmarman.2019.03.001

32. Chang, H.H., Wong, K.H., Li, S.Y.: Applying push-pull-mooring to investigate channel switching behaviors: M-shopping self-efficacy and switching costs as moderators. Electron. Commer. Res. Appl. 24, 50-67 (2017)

33. Groß, M.: Mobile shopping loyalty: the salient moderating role of normative and functional compatibility beliefs. Technol. Soc. 55, 146-159 (2018)

34. Aldás-Manzano, J., Ruiz-Mafé, C., Sanz-Blas, S.: Exploring individual personality factors as drivers of M-shopping acceptance. Ind. Manag. Data Syst. 109, 739-757 (2009)

35. Groß, M.: Exploring the acceptance of technology for mobile shopping: an empirical investigation among Smartphone users. Int. Rev. Retail Distrib. Consum. Res. 25, 215-235 (2015)

36. Venkatesh, V., Morris, M.G., Davis, G.B., Davis, F.D.: User acceptance of information technology: toward a unified view. MIS Q. 27, 425-478 (2003)

37. Gupta, A., Arora, N.: Understanding determinants and barriers of mobile shopping adoption using behavioral reasoning theory. J. Retail. Consum. Serv. 36, 1-7 (2017)

38. Kim, M.J., Chung, N., Lee, C.-K., Preis, M.W.: Dual-route of persuasive communications in mobile tourism shopping. Telemat. Inform. 33, 293-308 (2016)

39. Gao, L., Waechter, K.A., Bai, X.: Understanding consumers' continuance intention towards mobile purchase: a theoretical framework and empirical study-a case of China. Comput. Hum. Behav. 53, 249-262 (2015)

40. Hew, J.-J., Leong, L.-Y., Tan, G.W.-H., Lee, V.-H., Ooi, K.-B.: Mobile social tourism shopping: a dual-stage analysis of a multi-mediation model. Tour. Manag. 66, 121-139 (2018)

41. Celik, H., Kocaman, R.: Roles of self-monitoring, fashion involvement and technology readiness in an individual's propensity to use mobile shopping. J. Syst. Inf. Technol. 19, 166-182 (2017)

42. Amoroso, D.L.: The importance of institution-based trust in mobile adoption with online shopping applications. Int. J. Technol. Diffus. (IJTD) 4, 1-26 (2013) 
43. Kim, C., Li, W., Kim, D.J.: An empirical analysis of factors influencing M-shopping use. Int. J. Hum.-Comput. Interact. 31, 974-994 (2015)

44. Chen, Y.-M., Hsu, T.-H., Lu, Y.-J.: Impact of flow on mobile shopping intention. J. Retail. Consum. Serv. 41, 281-287 (2018)

45. Groß, M.: Heterogeneity in consumers' mobile shopping acceptance: a finite mixture partial least squares modelling approach for exploring and characterising different shopper segments. J. Retail. Consum. Serv. 40, 8-18 (2018)

46. Lu, H.-P., Su, P.Y.-J.: Factors affecting purchase intention on mobile shopping web sites. Internet Res. 19, 442-458 (2009)

47. Natarajan, T., Balasubramanian, S.A., Kasilingam, D.L.: The moderating role of device type and age of users on the intention to use mobile shopping applications. Technol. Soc. 53, 7990 (2018)

48. Saprikis, V., Markos, A., Zarmpou, T., Vlachopoulou, M.: Mobile shopping consumers' behavior: an exploratory study and review. J. Theor. Appl. Electron. Commer. Res. 13, $71-$ 90 (2018)

49. Shang, D., Wu, W.: Understanding mobile shopping consumers' continuance intention. Ind. Manag. Data Syst. 117, 213-227 (2017)

50. Chau, N.N., Seshadri, S., Broekemier, G., Pamornpathomkul, S.: An exploratory study of mobile shopping behaviors of young adults in Thailand. J. Internet Commer. 17, 339-355 (2018)

51. Lu, J., Yu, C.-S., Liu, C., Wei, J.: Comparison of mobile shopping continuance intention between China and USA from an espoused cultural perspective. Comput. Hum. Behav. 75, 130-146 (2017)

52. Tan, G.W.-H., Ooi, K.-B.: Gender and age: do they really moderate mobile tourism shopping behavior? Telemat. Inform. 35, 1617-1642 (2018)

53. Yang, K., Forney, J.C.: The moderating role of consumer technology anxiety in mobile shopping adoption: differential effects of facilitating conditions and social influences. J. Electron. Commer. Res. 14, 334 (2013)

54. Yang, K.: Determinants of US consumer mobile shopping services adoption: implications for designing mobile shopping services. J. Consum. Mark. 27, 262-270 (2010)

55. Hung, M.-C., Yang, S.-T., Hsieh, T.-C.: An examination of the determinants of mobile shopping continuance. Int. J. Electron. Bus. Manag. 10, 29 (2012)

56. Kang, C.-R., Hung, M.-C., Yang, S.-T., Hsieh, T.-C., Tang, S.-M.: Factors affecting the continued intention of mobile shopping. In: 2010 IEEE International Conference on Industrial Engineering and Engineering Management, pp. 710-713. IEEE (2010)

57. Groß, M.: Impediments to mobile shopping continued usage intention: a trust-riskrelationship. J. Retail. Consum. Serv. 33, 109-119 (2016)

58. Marriott, H.R., Williams, M.D.: Exploring consumers perceived risk and trust for mobile shopping: a theoretical framework and empirical study. J. Retail. Consum. Serv. 42, 133 146 (2018)

59. Prodanova, J., San-Martín, S., Jimenez, N.: Are you technologically prepared for mobile shopping? Serv. Ind. J. 1-23 (2018). https://doi.org/10.1080/02642069.2018.1492561

60. Yang, K.: Consumer technology traits in determining mobile shopping adoption: an application of the extended theory of planned behavior. J. Retail. Consum. Serv. 19, 484 491 (2012)

61. Bandura, A.: Social Foundation of Thought and Action: A Social-Cognitive View. Prentice Hall, Englewood Cliffs (1986)

62. Ajzen, I.: The theory of planned behavior. Organ. Behav. Hum. Decis. Process. 50, 179-211 (1991)

63. Rogers, E.: Diffusion of Innovations. Free Press, New York (1995) 
64. Davis, F.D.: Perceived usefulness, perceived ease of use, and user acceptance of information technology. MIS Q. 13, 319-340 (1989)

65. Davis, F.D., Bagozzi, R.P., Warshaw, P.R.: Extrinsic and intrinsic motivation to use computers in the workplace. J. Appl. Soc. Psychol. 22, 1111-1132 (1992)

66. Peter, J.P., Ryan, M.J.: An investigation of perceived risk at the brand level. J. Mark. Res. 13, 184-188 (1976)

67. Agarwal, R., Prasad, J.: A conceptual and operational definition of personal innovativeness in the domain of information technology. Inf. Syst. Res. 9, 204-215 (1998)

68. Oliver, R.L.: Measurement and evaluation of satisfaction processes in retail settings. J. Retail. 57, 25-48 (1981)

69. McKnight, D.H., Chervany, N.L.: What trust means in e-commerce customer relationships: an interdisciplinary conceptual typology. Int. J. Electron. Commer. 6, 35-59 (2001)

70. Bhattacherjee, A.: Understanding information systems continuance: an expectationconfirmation model. MIS Q. 25, 351-370 (2001)

71. DeLone, W.H., McLean, E.R.: Information systems success: the quest for the dependent variable. Inf. Syst. Res. 3, 60-95 (1992)

72. Chen, L.Y.: The quality of mobile shopping system and its impact on purchase intention and performance. Int. J. Manag. Inf. Technol. 5, 23 (2013)

73. Wu, J., Du, H.: Toward a better understanding of behavioral intention and system usage constructs. Eur. J. Inf. Syst. 21, 680-698 (2012) 